\title{
HUBUNGAN ANTARA PARITAS DENGAN KEJADIAN KANKER SERVIKS DI YAYASAN KANKER WISNUWARDHANA SURABAYA
}

\author{
Sisca Nida Mayrita *, Nanik Handayani ** \\ (UNUSA, J1. SMEA 57 Surabaya) \\ Email : nanik_handayani.ac.id
}

\begin{abstract}
Cervical cancer is a malignant disease attacked the female reproductive organ which is often found in women with high parity. The data obtained from Yayasan Wisnuwardhana Surabaya (Cancer Foundation) in 2012 showed that among 9630 women having Pap Smear, $88(0.9 \%)$ were detected with cervical cancer. Therefore, the purpose of this study was to find out the correlation between parity and incidence of cervical cancer in the above mentioned cancer foundation. The design of study was analytic-observational done by applying cross sectional approach. The population involved 400 women having Pap Smear in the stated cancer foundation in March 2014. 200 respondents were chosen as the samples by using probability sampling, in which simple random sampling technique was used in this study. The instrument for collecting the data was the medical record. The data were then analyzed by using Chi-Square statistic test with the significance level $\alpha=0.05$. The result of study showed that none of the nullipara and primipara $(0 \%)$ suffered from cervical cancer, whereas few of the multipara (5.9\%) and half of the grandemultipara (50\%) suffered from cervical cancer. Moreover, the result of Chi-Square was not qualified so that Fischer's Exact test was used and showed that $\mathrm{p}=0.000<\alpha=0.05$ so that $\mathrm{H}_{0}$ was rejected illustrating that there was a correlation between parity and incidence of cervical cancer in the above mentioned cancer foundation.In conclusion, the higher parity, the more risk for cervical cancer. The facility of health services are expected to give more health counseling to the women with high risk of having cervical cancer to have Pap Smear.
\end{abstract}

Abstrak:Kanker serviks merupakan penyakit keganasan alat kandungan wanita, yang terbanyak dijumpai pada wanita yang sering partus. Data yang diperoleh dari Yayasan Wisnuwardhana Surabaya pada tahun 2012 wanita yang melakukan pap smear sebanyak 9630 dan yang terdeteksi kanker servik sebanyak $88(0,9 \%)$ wanita. Penelitian ini bertujuan untuk mengetahui hubungan paritas dengan kejadian kanker serviks di Yayasan Wisnuwardhana Surabaya.Rancangan penelitian menggunakan analitik observasional dengan pendekatan cross sectional. Populasi dalam penelitian ini adalah seluruh wanita yang melakukan pap smear di Yayasan Kanker Wisnuwardhana Surabaya sebesar 400 orang pada bulan Maret 2014. Sampel berjumlah 200 orang diambil secara probability sampling tipe simple random sampling. Instrumen berupa rekam medik. Analisis data menggunakan uji statistik Chi-Square dengan tingkat kemaknaan $\alpha=0,05$. Hasil penelitian diperoleh bahwa tidak satupun $(0 \%)$ nullipara dan primipara menderita kanker serviks, sedangkan sebagian kecil $(5,9 \%)$ multipara dan setengahnya $(50 \%)$ grandemulti menderita kanker serviks. Hasil uji Chi-Square tidak memenuhi syarat maka digunakan uji Fisher Exact dan didapatkan nilai $\mathrm{p}=0,000<\alpha=0,05$ maka Ho ditolak artinya ada hubungan paritas dengan kejadian kanker serviks di Yayasan Kanker Wisnuwardhana Surabaya.Simpulan yaitu semakin tinggi paritas semakin besar resiko terkena kanker serviks. Diharapkan tempat pelayanan kesehatan untuk lebih memberikan penyuluhan kesehatan pada wanita yang beresiko tinggi terkena kanker serviks untuk melakukan pap smear.

Kata kunci : paritas, kanker serviks. 


\section{PENDAHULUAN}

Kanker serviks merupakan penyakit keganasan yang menimbulkan masalah dalam kesehatan kaum wanita. Kanker serviks telah menempati urutan terbanyak kedua setelah kanker payudara. Bahkan penderita kanker serviks semakin meningkat dari tahun ke tahun terutama pada negara berkembang. Kanker serviks sulit dideteksi dan begitu terdeteksi sering kali sudah berada pada stadium lanjut sehingga sulit untuk di tangani. Hal tersebut menyebabkan kanker serviks menjadi momok bagi setiap penderitanya.

Ada beberapa kejadian kanker serviks yang disebabkan oleh perempuan dengan mitra seksual multipel, aktivitas seksual dini, perempuan yang merokok, status sosial ekonomi dan salah satunya adalah paritas. Menurut hasil penelitian dari Melva (2008), jumlah kehamilan >3 kali merupakan faktor prospektif terhadap kejadian kanker serviks. Kanker serviks banyak ditemukan pada wanita yang melahirkan 3-5 kali. Bagi banyak orang tua, beranggapan bahwa banyak anak maka akan banyak rejeki. Akan tetapi, masyarakat banyak yang belum mengerti tentang akibat yang ditimbulkan dari seringnya seorang ibu melahirkan. Dengan seorang ibu sering melahirkan dan memiliki banyak anak maka akan menyebabkan hormon selama kehamilan dan perlukaan pasca persalinan berubah menjadi sel kanker.

Menurut World Health Organitation (WHO, 2009) didapatkan data 500.000 sampai 1 juta kasus baru terinfeksi kanker serviks setiap tahunnya. Sedangkan menurut data dari Globocan pada tahun 2008, didapatkan data pada kasus kanker servik di seluruh dunia mencapai 530.232 kasus . Asia memiliki 312.990 kasus kanker serviks dan baik dari jumlah global maupun Asia 58\% meninggal. Sebanyak 2,2 juta perempuan di dunia menderita kanker servik. Setiap tahunnya, terdapat kurang lebih 400.000 kasus baru kanker serviks, dan sebanyak
$80 \%$ terjadi pada wanita yang hidup di negara berkembang. Negara Indonesia memiliki penderita kanker serviks terbanyak dibandingkan dengan negara berkembang lainnya. Di Indonesia sekarang diperkirakan dalam setiap harinya terjadi 41 kasus baru kanker serviks dan sekitar 20 orang setiap harinya meninggal dunia. (Globocan, 2008)

Menurut data Dinas Kesehatan Jawa Timur didapatkan data penderita kanker serviks pada tahun 2009 sebanyak 671 orang, pada tahun 2010 sebanyak 868 orang. Sedangkan pada tahun 2011 didapatkan data 1028 orang menderita kanker servik dan pada tahun 2012 mencapai angka 1224 orang. Angka tersebut menjadikan Jawa Timur sebagai peringkat pertama kasus kanker serviks tingkat nasional. Dan menjadi musuh utama pada wanita karena penderita kanker yang semakin banyak dari tahun ke tahunnya (Dinkes Jatim Pemprov, 2012). Data yang diperoleh dari Yayasan Wisnuwardhana Surabaya pada tahun 2011 wanita yang melakukan pemeriksaan pap smear sebanyak 11086 wanita dan yang terdeteksi kanker serviks sebanyak 112 wanita. Sedangkan pada tahun 2012 wanita yang melakukan pap smear sebanyak 9630 dan yang terdeteksi kanker servik sebanyak 88 wanita

Faktor risiko terjadinya kanker serviks pada wanita adalah perempuan dengan mitra seksual multipel, aktivitas seksual dini, perempuan yang merokok, paritas, status sosial ekonomi (Ralph, 2008). Paritas yang berbahaya adalah memiliki anak lebih dari 2 orang atau jarak persalinan yang terlalu dekat. Wanita dengan paritas tinggi yaitu $>3$ kali berisiko 5,5 kali untuk terkena kanker servik (Diananda, 2007). Wanita dengan paritas tinggi dapat menyebabkan trauma pada jalan lahir dan dapat menimbulkan sel-sel abnormal pada mulut rahim jumlah anak yang dilahirkan melalui jalan normal dapat menyebabkan terjadinya perubahan sel abnormal dari epitel pada mulut rahim dan dapat berkembang menjadi keganasan. 
Oleh karena itu, sebagai tenaga kesehatan perlu menumbuhkan kesadaran diri pada wanita dalam melakukan deteksi dini terhadap kanker servik serta berperilaku hidup sehat dan bersih. Jika pada pemeriksaan awal ibu tidak terkena kanker servik maka dapat dilakukan pencegahan

\section{METODE}

Penelitian ini menggunakan desain analitik observasional, dengan pendekatan Cross Sectional.Populasinya yaitu seluruh wanita yang melakukan pap smear di Yayasan Kanker Wisnuwardhana Surabaya sebesar 400 orang pada bulan Maret 2014.Sampel nya sejumlah 200 orang Teknik sampling yang di gunakan probability sampling dengan metode pendekatan simple random sampling, Variabel independen atau variabel bebas dalam penelitian ini adalah paritas sedangkan Variabel dependen atau variabel terikat dalam penelitian ini adalah kanker serviks. Instrumennya menggunakan rekam medik.Uji nya menggunakan $\mathrm{Chi}$ Square untuk menganalisis data dengan tingkat signifikansi $\alpha=0,05$.

\section{HASIL DAN PEMBAHASAN}

\section{A. Hasil}

Penelitian ini dilakukan di Yayasan Kanker Wisnuwardhana terletak di jalan Kayon no. 16-18 Surabaya, dengan luas tanah $1.327 \mathrm{~m}^{2}$ dan luas bangunan $600 \mathrm{~m}^{2}$. Hasil penelitian pada 200 responden pendidikannya hampir setengah responden $(43,0 \%)$ berpendidikan menengah (SMA).Hampir seluruhnya responden $(81,5 \%)$ berusia lebih dari 35 tahun.Usia pada saat menikah sebagian besar responden $(71,5 \%)$ berusia lebih dari 20 tahun.Berdasarkan paritas sebagian besar responden $(59,0 \%)$ memiliki anak 2-4 anak (Multipara). dengan vaksinasi. Namun, bagi ibu yang sudah terkena kanker servik maka harus segera diberikan pelayanan kesehatan sesuai dengan stadium yang diderita untuk mencegah terjadinya metase (penyebaran ke organ lain).

berdasarkan data kejadian kanker hampir seluruh responden $(90,5 \%)$ tidak menderita kanker serviks.

\section{B.Pembahasan}

1. Paritas

Paritas adalah jumlah kehamilan yang menghasilkan janin yang mampu hidup di luar rahim (28 minggu) Hasil penelitian menunjukkan bahwa sebagian besar responden $(59,0 \%)$, merupakan paritas dengan risiko tinggi yaitu memiliki 2-4 orang anak (multipara).Paritas dapat dipengaruhi oleh beberapa faktor salah satunya adalah pendidikan, hampir setengahnya (43\%) responden berpendidikan menengah (SMA). Pendidikan berarti bimbingan yang diberikan oleh seseorang terhadap perkembangan orang lain menuju ke arah suatu cita-cita tertentu. Makin tinggi tingkat pendidikan seseorang, maka makin mudah dalam memperoleh menerima informasi, sehingga kemampuan ibu dalam berpikir lebih rasional. Ibu yang mempunyai pendidikan tinggi akan lebih berpikir rasional bahwa jumlah anak yang ideal adalah 2 orang.

Tingkat pendidikan ibu yang rendah mengakibatkan kurangnya pengetahuan ibu dalam menghadapi masalah, sedangkan ibu-ibu yang mempunyai tingkat pendidikan yang lebih tinggi umumnya terbuka menerima perubahan atau hal-hal baru guna pemeliharaan kesehatannya. Suatu proses pertumbuhan dan perkembangan manusia, usaha mengatur pengetahuan semula yang ada pada seorang individu serta pendidikan juga menjadi tolak ukur yang penting dalam perubahan-perubahan perilaku yang 
positif. semakin tinggi tingkat pendidikan seseorang maka semakin membutuhkan pusat-pusat pelayanan kesehatan sebagai tempat berobat bagi dirinya dan keluarganya. Dengan pendidikan tinggi, maka wawasan pengetahuan semakin bertambah dan semakin menyadari bahwa begitu pentingnya kesehatan bagi kehidupan sehingga termotivasi untuk melakukan kunjungan ke pusat pelayanan kesehatan yang lebih baik (Notoatmodjo, 2003).

\section{Kanker Serviks}

Hasil penelitian didapatkan hampir seluruh responden $(90,5 \%)$ tidak menderita kanker serviks. Hal itu disebabkan ibu yang melakukan pemeriksaan pap smear datang sebelum timbulnya gejala seperti menstruasi yang terus menerus, perdarahan pasca senggama, keputihan yang berlebihan. Hal itu dilakukan untuk mendeteksi dini kanker serviks, karena kanker serviks pra-invasif atau pra-kanker bisa tanpa adanya keluhan tetapi lesi pada mulut rahim dapat berubah menjadi ganas apabila tidak segera diobati. Masa pertumbuhan kanker serviks, masa preinvasif (pertumbuhan sel-sel abnormal sebelum menjadi keganasan) penyakit ini terbilang lama sehingga penderita yang berhasil mendeteksinya sejak dini dapat melakukan berbagai langkah untuk mengatasinya. Infeksi menetap akan menyebabkan pertumbuhan sel abnormal yang akhirnya dapat mengarah pada perkembangan kanker, perkembangan ini memakan waktu 5-20 tahun. Dimulai dari tahap infeksi, lesi pra-kanker hingga positif menjadi kanker serviks (Nurwijaya, 2010).Kanker serviks dipengaruhi oleh beberapa faktor salah satunya adalah usia responden.Hampir seluruh responden $(81,5 \%)$ yang melakukan pap smear berusia lebih dari 35 tahun, usia ini adalah usia dengan risiko tinggi terkena kanker serviks. Kanker serviks menyerang pada wanita yang sudah menikah terutama yang aktif melakukan hubungan seksual selama 3 tahun. Resiko kanker serviks makin besar sering dengan bertambahnya usia.hal ini disebabkan pada usia $>35$ tahun fungsi semua organ tubuh menurun, disamping itu hormon dalam tubuh yang mempengaruhi pertumbuhan dan perkembangan sel di dalam tubuh yang dapat menyebabkan degenerasi sel. Hal ini sesuai pendapat dari Soehermawan (2007) bahwa usia rata-rata kejadian kanker servik adalah 52 tahun dan distribusi kasus mencapai puncak 2 kali pada usia di atas 35 tahun. Sedangkan menurut Nia Kania (2007) bahwa salah satu faktor resiko kanker serviks adalah usia > 40 tahun. Pada masa itu terjadi perubahan hormon yang dapat meningkatkan atau menurunkan sensifitas terhadap karsinogen.Faktor lainnya adalah usia pertama kali menikah. Sebagian besar responden $(71,5 \%)$ menikah diusia lebih dari 20 tahun. Usia lebih dari 20 tahun adalah usia produktif aman sampai seorang wanita berusia 35 tahun. Pada usia lebih dari 20 tahun wanita boleh untuk melakukan hubungan seksual dan terjadi kehamilan dikarenakan usia lebih dari 20 tahun organ reproduksi wanita bisa dikatakan sudah matang. Apabila seorang wanita melakukan hubungan seksual dengan usia dibawah 20 tahun maka rangsangan tersebut dapat mengakibatkan luka kecil yang dapat mengundang virus penyebab kanker masuk.Umumnya sel-sel mukosa baru matang setelah wanita berusia 20 tahun ke atas bukan dilihat dari menstruasi seorang wanita. Serviks pada remaja lebih rentan terhadap stimulus karsinogen karena terdapat proses metaplasia skuamos yang aktif yang dapat menyebabkan terjadinya kanker serviks, yang artinya organ reproduksi remaja rentan terhadap rangsangan sehingga pada usia dibawah 20 tahun belum siap mendapatkan rangsangan dari luar (Rama Diananda, 2009)
C. Hubungan paritas dengan kejadian kanker serviks
Berdasarkan hasil uji statistik fisher exact test didapatkan nilai $\rho=0,000$ dan


$\alpha=0,05$ sehingga $\rho<\alpha$ maka $H_{0}$ ditolak berarti ada hubungan antara paritas dengan kejadian kanker serviks di Yayasan Kanker Wisnuwardhana Surabaya. Didapatkan data seluruh responden (100\%) yang tidak memiliki anak (nullipara) dan wanita yang memiliki anak 1 (primipara) tidak menderita kanker serviks. Sedangkan pada wanita yang memiliki 2-4 anak (multipara) didapatkan data bahwa sebagian kecil $(5,9 \%)$ menderita kanker serviks dan dari wanita yang mempunyai anak lebih dari 4 (grandemultipara) didapatkan data bahwa setengahnya $(50 \%)$ menderita kanker serviks.

$$
\text { Pada mereka yang pernah }
$$

melahirkan lebih dari 3 kali dapat meningkatkan angka kejadian kanker sebanyak 3 kali lipat. Perlukaan pasca persalinan dapat menjadikan awal terjadinya kanker serviks apabila tidak segera ditangani. Bukan hanya perlukaan pasca persalinan yang menyebabkan terjadinya kanker serviks tetapi jarak persalinan yang terlalu dekat juga dapat menyebabkan terjadinya kanker serviks (Erik Tapan, 2010).Hal ini Menggambarkan semakin banyak jumlah anak semakin beresiko mengalami kanker serviks. Seseorang yang memiliki banyak anak terutama yang melahirkan lebih dari 3 kali akan menjadi resiko tinggi terkena kanker serviks. Dikarenakan perlukaan setelah melahirkan dan jarak persalinan yang terlalu dekat akan menyebabkan virus penyebab kanker servik masuk.

Kanker servik atau kanker leher rahim merupakan penyebab kematian akibat kanker terbesar bagi wanita. Kanker ini terjadi pada area leher rahim yaitu bagian rahim yang menghubungkan rahim bagian atas dengan vagina (Soehermawan, 2007). Pada umumnya kanker servik paling banyak ditemukan pada wanita yang sering melahirkan. Hal ini di duga akibat perubahan hormonal yang terjadi selama kehamilan dan trauma servikal yang terjadi saat melahirkan. Hal itu yang dapat menyebabkan virus HPV masuk dan berubah menjadi kanker. Kehamilan juga dihubungkan dengan terjadinya immnusuppresion yang memungkinkan terjadinya proses keganasan dan replika HPV(ACCP, 2004).

Kanker serviks bisa juga disebabkan karena serviks yang normal secara alami mengalami proses metaplasia (erosio) akibat saling desak mendesaknya kedua jenis epitel yang melapisi dengan masuknya mutagen, porsio yang erosif (metaplasia skuamosa) yang semula fisiologik dapat berubah menjadi patologik melalui tingkatan NIS-I, II, III dan KIS untuk akhirnya menjadi karsinoma invasif. Sekali menjadi mikro invasif, proses keganasan akan berjalan terus. Periode laten (dari NIS-I sampai dengan KIS) tergantung dari daya tahan tubuh penderita. Umumnya dari fase pra invasif menjadi invasif memakan waktu bertahuntahun dan umumnya tanpa disertai gejala sehingga ditemukan sudah dalam keadaan stadium lanjut (Prawirohardjo, 2007).

Menurut Surbakti (2004) bahwa wanita dengan jumlah paritas lebih dari 3 memiliki resiko 4 kali lebih besar terkena kanker serviks. Menurut Manuaba (2002), peningkatan kejadian infeksi semakin besar pada kehamilan dan persalinan. Diperkirakan risiko 3-5 kali lebih besar pada wanita yang sering partus.

Wanita yang memiliki anak lebih dari 3 mempunyai risiko menderita kanker serviks dibandingkan dengan wanita yang memiliki anak dibawah 3. Karena paritas merupakan faktor risiko kanker serviks. Dengan banyaknya kehamilan sehingga dalam proses melahirkan anak mungkin saja memiliki efek trauma atau pun juga karena efek penurunan imunitas tubuh sehingga meningkatkan risiko infeksi HPV.

Trauma pada jalan lahir tersebut apabila tidak mendapatkan pengobatan dapat menjadi perlukaan yang menahun, yang dapat menimbulkan infeksi alat genetalia bagian atas dan perlukaan yang tidak sembuh dapat menjadi keganasan. Selain itu juga bisa karena pengaruh hormonal pada saat kehamilan telah 
berpengaruh pada serviks yaitu pengaruh hormone progesterone yang membuat kemungkinan infeksi oleh HPV semakin mudah.

Kurangnya pengetahuan masyarakat akan bahaya memiliki banyak anak juga dapat memicu terjadinya kanker serviks. Masyarakat beranggapan banyak anak maka akan banyak rejeki. Padahal anggapan itu salah, hal itu justru meningkatkan resiko terjadinya kanker serviks. Kanker serviks dapat menyebabkan komplikasi yang parah yaitu anemia, penurunan berat badan dan infeksi yang menyebabkan kekurangan protein dan zat besi akibat pengobatan konvensional. Mengingat bahaya dari penyakit kanker serviks seharusnya masyarakat dapat berpikir cerdas untuk menjaga kesehatan reproduksi dan mengikuti program pemerintah yaitu KB untuk membatasi persalinan agar risiko

\section{SIMPULAN DAN SARAN}

\section{A. Simpulan}

Berdasarkan pembahasan yang telah diuraikan dari peneliti yang dilakukan pada wanita yang melakukan pemeriksaan pap smear di Yayasan Kanker Wisnuwardhana Surabaya dapat disimpulkan :

1. Ibu yang melakukan pap smear sebagaian besar memiliki paritas multipara (2-4 anak).

2. Ibu yang melakukan pap smear sebagian kecil menderita kanker serviks

3. Ada hubungan antara paritas dengan kejadian kanker serviks, dimana kejadian kanker servik terjadi pada ibu yang berisiko tinggi yaitu ibu yang mempunyai anak 2-4 anak (multipara) dan yang memiliki anak lebih dari 4 (grandemultipara)

\section{B. Saran}

1. Tempat pelayanan kesehatan terjadi kanker servik semakin sedikit. Mengetahui kanker secara dini sangat penting. Karena merupakan cara yang paling mungkin untuk melawan kanker serviks. Untuk mengetahui kanker serviks secara dini pemeriksaan papsmear yang teratur akan sangat membantu. Selain itu menghindari faktor risiko juga sangat penting untuk mencegah terjadinya kanker serviks. Di Yayasan kanker Wisnuwardhana Surabaya telah dilakukan pengobatan, operasi, berobat jalan dan kemoterapi. Pengobatan tersebut tidak menutup kemungkinan untuk berhasil atau tidak karena tergantung dari stadium penyakitnya. Jika sudah ditemukan dalam stadium sedini mungkin maka dapat disembuhkan secara optimal dan perlu kontrol kembali untuk mengetahui keberhasilan terapinya.

Diharapkan dapat mengadakan promosi kesehatan tentang pencegahan kanker serviks di berbagai tatanan pelayanan kesehatan (RS, Puskesmas, BPS, Klinik swasta) melalui leaflet, serta perlu memotivasi bagi wanita yang sudah terkena kanker serviks untuk melakukan pengobatan dan bagi wanita yang belum terkena kanker serviks untuk melakukan vaksinasi.

2. Bagi peneliti selanjutnya

Perlu dilanjutkan penelitian yang lebih lanjut untuk mengetahui faktor-faktor lain yang dapat mempengaruhi terjadinya kanker serviks sehingga dapat mengurangi kejadian kanker servik

3. Bagi masyarakat

Diharapkan masyarakat khususnya ibu yang sudah pernah melahirkan untuk mencari informasi tentang bahaya kanker serviks dan deteksi dini melalui pemeriksaan pap smear, di samping itu dukungan keluarga untuk memberikan motivasi hidup pada wanita yang menderita kanker serviks. 


\section{DAFTAR PUSTAKA}

ACCP (2004). Cervical Cancer Prevention Fact Sheet. Available from : http://www.mediaindonesia.com/berita/asp [accessed 16 April 2014].

Aziz, M.F. (2007). Program Pencegahan Kanker Serviks See and Treat. Jakarta, FK UI.

Benson, Ralph C. (2008). Buku Saku Obstetri dan Ginekologi $9^{\text {th }}$ ed. Jakarta, EG

Bobak (2004). Buku Ajar Keperawatan Maternitas. Jakarta, rineka cipta

Dalimarta, S. (2004). Deteksi Dini Kanker. Jakarta, Penebar Swadaya

Depkes (2008). Buku saku pencegahan kanker servik dan kanker payudara. Available from

http://www.pppl.depkes.go.id/_.../bukus aku kanker.pdf [accessed 05 Januari 2014].

Diandana, dr Rama. (2009). Panduan Lengkap Mengenal Kanker. Jogjakarta, Mirza Media Pustaka

Dizon, Don S, dkk. (2009). 100 Tanya Jawab Mengenai Kanker Serviks. Jakarta, Indeks

Mahalayati (2010). Solusi murah Untuk Cantik, Sehat, Energik. Yogyakarta, Great publisher

Manuaba (2002). Kapita Selekta Penatalaksanaan Rutin Obstretri Ginekologi/KB $1^{\text {st }}$ ed. Jakarta, Buku Kedokteran EGC

Manuaba (2008). Ilmu kebidanan, kandungan dan $K B$. Jakarta, EGC

Medicastrore (2014). Kanker Leher Rahim (Serviks). Available from: http://medicastore.com/penyakit/104/Ka nker_Leher_Rahim_serviks.html.

[Accessed 05 Januari 2014]

Nurwijaya, dra Hartati, dkk. (2010). Cegah dan Deteksi Kanker Serviks. Jakarta, Elex Media Komputindo

Prawirhardjo (2007). Ilmu Kebidanan. Yogyakarta, Yayasan Bina Pustaka Sarwono Prawihardjo

Rasjidi, Imam. (2008). Manual Prakanker Serviks. Jakarta, Sagung Seto
Samadi, Heru Priyanto. (2011). Yes, I Know Everything About Kanker Serviks. Solo, Metagraf

Soeherman, Dedy. (2007). Hubungan Penurunan Kadar Squoamous Cell Carcinoma Antigen Dengan Respon Radiasi Histopatologis Pada Karsinoma Epidermoid Serviks Uteri Stadium Lanjut. Tesis. Semarang, Universitas Diponegoro

Suharto. (2007). Hubungan antara Karakteristik Ibu Dengan Partisipasi Ibu Melakukan Pemeriksaan Pap Smear Di Klinik Adhiwarga PKBI Yogyakarta. Skripsi. Yogyakarta, Universitas Ahmad Dahlan

Sukaca, Bertiani E. (2009). Cara Cerdas Menghadapi Kanker Serviks (Leher Rahim). Jogjakarta, Genius Pratika

Surbakti, E. (2004). Pendekatan Faktor Risiko Sebagai Rancangan Alternatif dalam Penanggulangan Kanker serviks Uteri di RSU Pringadi Medan. Medan, Tesis FK USU

Tapan, dr Erik. (2010). Kanker, Antioksidan dan Komplemen. Jakarta, Elexmedia

Varney, Helen (2006). Buku Ajar Asuhan Kebidanan Vol 1 Edisi 4. Jakarta, ECG

Yatim, dr Faisal. (2008). Penyakit Kandungan: Myoma, Kanker Rahim/Leher Rahim Dan Indung Telur, Kista, Serta Gangguan Lainnya. Jakarta, Pustaka Populer Obor. 